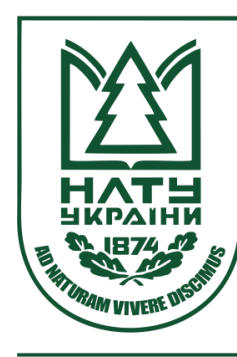

Науковий вісник НЛТУ України Scientific Bulletin of UNFU

https://nv.nltu.edu.ua

https://doi.org/10.15421/40290522

$@ \bowtie$ Correspondence author

Article received 08.05.2019 p.

Article accepted 30.05.2019 p.

M. F. Zayats

УДК 662.987:697.7

М. П. Кузик, М. Ф. Заяць

Національний університет "Львівська політехніка", м. Львів, Україна

\title{
ПАСИВНА СИСТЕМА СОНЯЧНОГО ТЕПЛОПОСТАЧАННЯ
}

Досліджено розрахунковим способом пасивне сонячне теплопостачання енергоощадного будинку в Чернівцях з розташованою в ньому стіною Тромбе-Мішеля, південна поверхня якої площею $8 \times 2,7$ м $^{2}$ нахилена до площини горизонту під кутом $67^{\circ}$ і відділена від навколишнього середовища подвійним склінням. Будівля є одноповерховим двокімнатним приміщенням 3 опалювальною площею $50 \mathrm{~m}^{2}$ і опалювальним об'ємом $150 \mathrm{~m}^{3}$. У підвалі будинку розташовано тепловий щебеневий акумулятор, який здатний зберігати до 2 ГДж теплоти за температури $75^{\circ} \mathrm{C}$. Влітку для зарядки акумулятора прогріте в проміжку між стіною Тромбе-Мішеля та склінням повітря відбирається вентилятором, продувається через акумулятор тепла, нагріваючи цим самим його теплоакумулятивну насадку. У жовтні-листопаді забране вентилятором 3 кімнати повітря проходить через акумулятор і нагріте повертається у приміщення. Встановлено сезонну залежність сумарного добового приходу тепла з урахуванням радіаційних втрат і використанням закумульованого тепла. Наведено розрахунок ефективності пасивної системи сонячного опалення розглянутої будівлі у Чернівцях за вказаних іiі об'єму, розміру стіни Тромбе-Мішеля і ємності теплового акумулятора, визначено коефіцієнти заміщення, з яких видно, що ступінь підтримки теплопостачання в осінні та весняні місяці може становити, залежно від значень теплового навантаження $\gamma$ (Вт/(м³ град)), від 25 до 100 \%.

Ключові слова: стіна Тромбе-Мішеля; акумулювання сонячної енергії; теплове навантаження; коефіцієнт заміщення.

Вступ. На потреби теплопостачання сьогодні в світі витрачається близько 25-30\% від усього органічного палива (Basok, 2014). В Україні на потреби опалення комунального житлового фонду щорічно використовується приблизно до 200 (кВт·год)/м² опалювальної площі (Basok, 2014), що зумовлено великими дисипативними втратами теплоти через огороджувальні будівельні конструкції будинків (вікна, стіни, дахи, підвали тощо). Якщо оперувати такою інтегральною, хоча і достатньо наближеною, характеристикою будівлі як ії̈ питоме теплове навантаження $\gamma\left(\mathrm{BT} /\left(\mathrm{M}^{3} \cdot\right.\right.$ град)), то при наведеній вище потребі теплоти на опалення вона становитиме приблизно $1,8 \mathrm{BT} /\left(\mathrm{m}^{3} \cdot\right.$ град). Це без урахування вентиляційних теплових втрат.

Енергоощадність у цій ситуації пов'язана зі застосуванням ефективних теплоощадних будівельних конструкцій і використанням поновлюваних та альтернативних джерел енергії, насамперед сонячної енергії, зручної для отримання низькопотенційного тепла. За кліматичними умовами Україна належить до регіонів із середньою інтенсивністю сонячної радіації. Ефективному використанню сонячної енергії в Україні сприяють кліматичні та географічні умови.

Досвід розроблення, будівництва й експлуатації енергоефективних будинків із системами сонячного теплопостачання, аналіз і узагальнення світових досяг- нень у цій галузі показують, що однією з найефективніших $є$ пасивна система сонячного опалення (Bozhko et al., 2015). Зокрема, вона реалізується у так названих "сонячних будинках", прикладом якого $є$ будівлі зі стіною Тромбе-Мішеля (стіна ТМ), які відомі і поширені в багатьох варіантах у різних країнах світу, наприклад (Zhijie, 2012; Boyer et al., 2011; Bellos et al., 2016; Tarnizhevskiy, 2000). В Україні теж реалізовані проекти енергоефективних будинків для наукових досліджень i в приватному житловому секторі (Bozhko et al., 2015; Honcharuk et al., 2014; Stepanenko \& Dubrovska, 2014). Проте в цих будівлях стіну ТМ не використовують. Це частково пов'язано з відсутністю досліджень про ефективність іiі застосування у кліматичних умовах на цій території.

Мета дослідження - проаналізувати розрахунковим методом ефективність сонячного пасивного теплопостачання будівлі зі стіною ТМ, яка розташована в Чернівцях. Згідно з ДСТУ-Н Б В.2.5-43:2010, Чернівці належать до першої кліматичної зони України (DSTU-N B V.2.5-43:2010, 2010). Річний прихід сонячної радіації на горизонтальну поверхню становить 1100-1150 (кВт·год)/ $\mathrm{m}^{2}$, а кількість годин сонячного сяйва за рік - 2016 год.

Матеріали та методи дослідження. Досліджувана будівля в Чернівцях - двокімнатне приміщення із внутрішніми розмірами: опалювальна площа $-50 \mathrm{~m}^{2}$, опалю-

Інформація про авторів:

Кузик Мирон Петрович, канд. фіз.-мат. наук, доцент, кафедра теплоенергетики, теплових і атомних електричних станцій. Email: kuzyk.lp@gmail.com; https://orcid.org/0000-0002-7359-1177

Заяць Марія Федорівна, ст. викладач, кафедра теплоенергетики, теплових і атомних електричних станцій. Email: marzayf@gmail.com; https://orcid.org/0000-0002-4374-3299

Цитування за ДСтУ: Кузик М. П., Заяць М. Ф. Пасивна система сонячного теплопостачання. Науковий вісник НлтУ України. 2019, т. 29, № 5. C. 111-114.

Citation APA: Kuzyk, M. P., \& Zayats, M. F. (2019). The passive system of the solar heat supply. Scientific Bulletin of UNFU, 29(5), $111-114$. https://doi.org/10.15421/40290522 
вальний об'єм - $150 \mathrm{~m}^{3}$ (рис. 1). Південний фасад приміщення завдовжки 8,5 м, заввишки 3,2 м, обернений на південь, має подвійне скління. Віддаль між шарами скла дорівнює 7 см. На середній віддалі 50 см від внутрішнього скла розташована стіна ТМ. Вона виконана 3 залізобетону, і з одного боку є несучим конструктивним елементом будівлі, а 3 другого - виконує роль приймача й акумулятора сонячної радіації і є основним елементом сонячного теплопостачання. У розрізі стінка ТМ має трапецієподібний профіль 3 основою 40 см, аналогічно використовуваної в (Zhijie, 2012) і нахилом південної поверхні, розміром $8 \times 2,7 \mathrm{~m}^{2}$, до площини горизонту $67^{\circ}$.

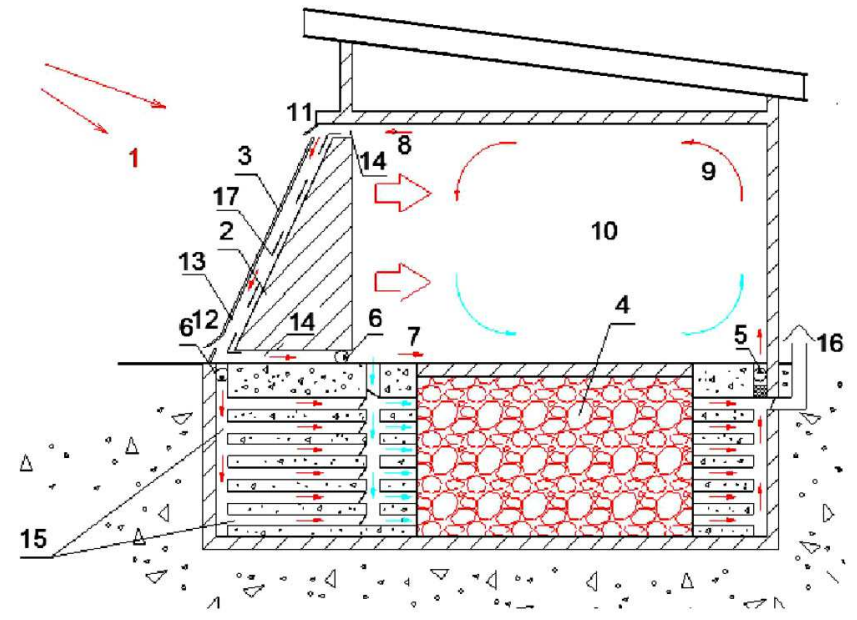

Рис. 1. Схема пасивної системи сонячного обігріву: 1) Сонце; 2) стіна Тромбе-Мішеля; 3) подвійне скління; 4) щебеневий акумулятор; 5, 6) вентилятори; 7) вхідний потік повітря; 8) висхідний потік повітря; 9) потік повітря, нагрітий в акумуляторі; 10) приміщення, що нагрівається; 11, 12) шибери у склінні; 13) проміжок між склінням; 14) циркуляційні канали у стінці Тромбе-Мішеля; 15) канали подавання повітря в тепловий акумулятор; 16) канал відведення повітря; 17) штора

У верхній і нижній частинах стіни ТМ є канали для циркуляції теплоносія (внутрішнього повітря). У період інсоляції стіна нагрівається. У нічний час повітря, що містяться у повітряному прошарку між стіною і склом, нагрівається і надходить через верхні канали у приміщення. Це повітря заміщає прохолодне, таке, що надходить 3 приміщення через нижні канали. Отже, завдяки природній гравітації відбувається циркуляція внутрішнього повітря приміщення через геліонагрівач. У нічний час внутрішня сторона скління накривається шторою $з$ теплоакумуляційного матеріалу для зменшення теплових втрат.

Коефіцієнт поглинання сонячної радіації стіни ТМ приймаємо на рівні 0,9. Втрату радіації під час проходження через скління приймаємо 0,17.

Для раціонального використання літньої сонячної радіації використовують розташований в утепленому підвальному приміщенні сезонний щебеневий тепловий акумулятор, який накопичує влітку теплоту, з наступним iï використанням у системі опалення взимку. Його об'єм становить $V_{\text {акум }}=4,5 \times 3 \times 2=27$ м $^{3}$. Зарядка акумулятора полягає в подаванні, за допомогою вентилятора, прогрітого влітку повітря в проміжку між стіною ТМ та склінням у щебеневий акумулятор тепла через канали. Залежно від температури зовнішнього середовища повітря або скидається в нього через канал відведення по- вітря, або, пройшовши фільтр, знову надходить через приміщення у згаданий проміжок. У жовтні-листопаді вентилятор відбирає повітря з кімнат, продуває його через акумулятор і вже нагріте повітря надходить знову в приміщення.

Результати дослідження. За допомогою сервісу http://solarelectricityhandbook.com/solar-rradiance.html знаходимо прихід радіації на поверхню під кутом $67^{\circ}$ до горизонту і орієнтацією на південь для Чернівців. Розрахунок приходу сонячної радіації $Q_{\text {рад }}$ на стіну ТМ за наведених вище розмірів проводимо для двох періодів: жовтень-листопад і березень-квітень (рис. 2).

Середньодобові втрати тепла $Q_{\text {втрат }}$ через випромінювання поверхнею стінки визначено за формулою випромінювання тіла 3 температурою $T_{\text {стінки }}$ у безмежний простір з температурою навколишнього середовища $T_{\text {зовн }}$ впродовж 10 год, тобто впродовж приблизно світлового дня. У нічний час 3 внутрішньої сторони скління опускався теплоізоляційний екран, який різко зменшував радіаційні втрати. 3 довідникової літератури

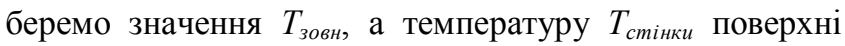
стінки розраховано. Для жовтня-листопада та березняквітня ці втрати 3 поверхні стінки не перевищували 25 МДж в добу. Ці розрахунки, очевидно, дуже спрощені, зорієнтовані в бік більших втрат.
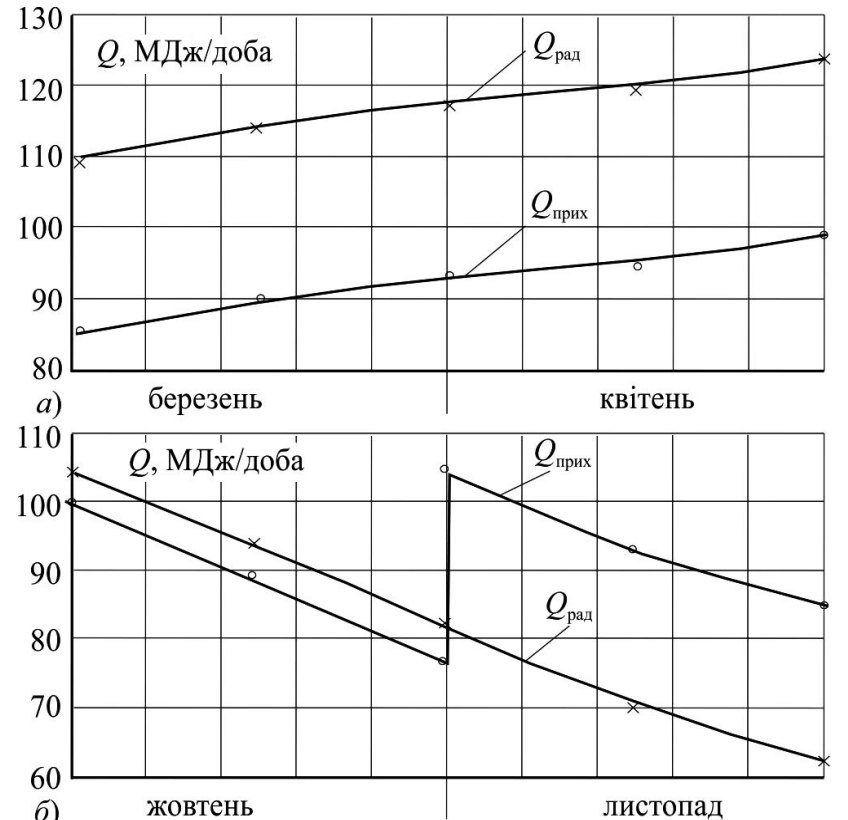

Рис. 2. Сезонна залежність добового приходу сонячної радіації $Q_{p a д}$ на стіну ТМ та сумарного добового приходу тепла $Q_{n p u x}$ : a) у березні-квітні; б) у жовтні-листопаді

Враховуємо подавання теплоти від щебеневого акумулятора, отже, ця теплота $Q_{\text {акум }}$ на момент початку "розрядки" становить

$$
Q_{\text {акум }}=\rho \cdot \kappa \cdot C_{P} \cdot V_{\text {акум }} \cdot\left(t_{\text {акум }}-18\right) \cdot(1-0,15)=2,06, \text { ГДж, }
$$

де: $\rho=2500$ кг $/ \mathrm{M}^{3}$ - густина щебеню, $\kappa=0,7-$ коефіцієнт його щільності; $C_{p}=0,90$ кДж/(кг.град) - теплоємність щебеню; 0,15 - середній коефіцієнт втрат акумулятора; $t_{\text {акум }}=75{ }^{\circ} \mathrm{C}$ - температура зарядженого акумулятора.

Відлік акумульованого тепла визначено відносно температури $18{ }^{\circ} \mathrm{C}$, тобто температури повітря, яка взимку підтримується у приміщенні. Для використання у жовтні відводимо з акумулятора приблизно третину 
$Q_{\text {акум }}$, а решта використовується в листопаді. У разі рівномірного впродовж місяця використання акумульованого тепла його добовий прихід в опалюване приміщення становить 20 МДж на добу для жовтня і 48 МДж на добу для листопада.

Встановлено сезонну залежність сумарного добового приходу тепла $Q_{n p u x} 3$ урахуванням радіаційних втрат та використання теплоти акумулятора (рис. 2). Загальну

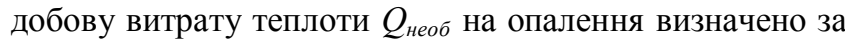
формулою

$$
Q_{\text {необ }}=\gamma \cdot V \cdot\left(t_{\text {прим }}-t_{\text {зовн }}\right) \cdot 3600 \cdot 24+Q_{\text {витр.вент }},
$$

де: $\gamma$ - питома тепловитрата на опалення будинку (теплове навантаження) за опалювальний період, що являє собою теплові втрати будинку, віднесені до одиниці опалювального об'єму і різниці температур ззовні і всередині будинку на один градус, Вт/ $\left(\mathrm{M}^{3} \cdot{ }^{\circ} \mathrm{C}\right) ; V-$ об'єм приміщення; $t_{\text {прим }}-$ температура приміщення, яку

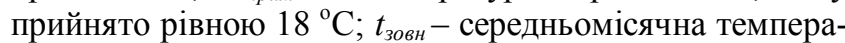
тура зовнішнього повітря у Чернівцях, яку на підставі довідникових даних (Nauchno-prykladnoi spravochnyk po klymatu SSSR, 10 ed., 1990) прийнято такою, що дорівнює 8,$7 ; 2,3 ; 1,7$ і $8,3{ }^{\circ} \mathrm{C}$ відповідно для жовтня, листопада, березня і квітня; $Q_{\text {витр.вент. }}=15 \cdot \mathrm{V} \cdot \mathrm{C}_{p}{ }^{\text {nов }}\left(t_{\text {прим }}\right.$ $\left.t_{3 о в н}\right)$ - витрати тепла на вентиляцію приміщення за кратності вентиляції $15 ; C_{p}{ }^{\text {nов }}=1,32$ кДж/( $\left.\mathrm{м}^{3} \cdot \mathrm{K}\right)$ - об'ємна теплоємність повітря.

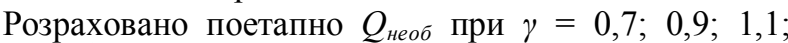
$1,3 \mathrm{BT} /\left(\mathrm{м}^{3} \cdot{ }^{\circ} \mathrm{C}\right)$. Стрибки на графіках (див. рис. 2, б і 3,б) пов'язані 3 різними величинами добової подачі акумульованої теплоти у жовтні та листопаді.
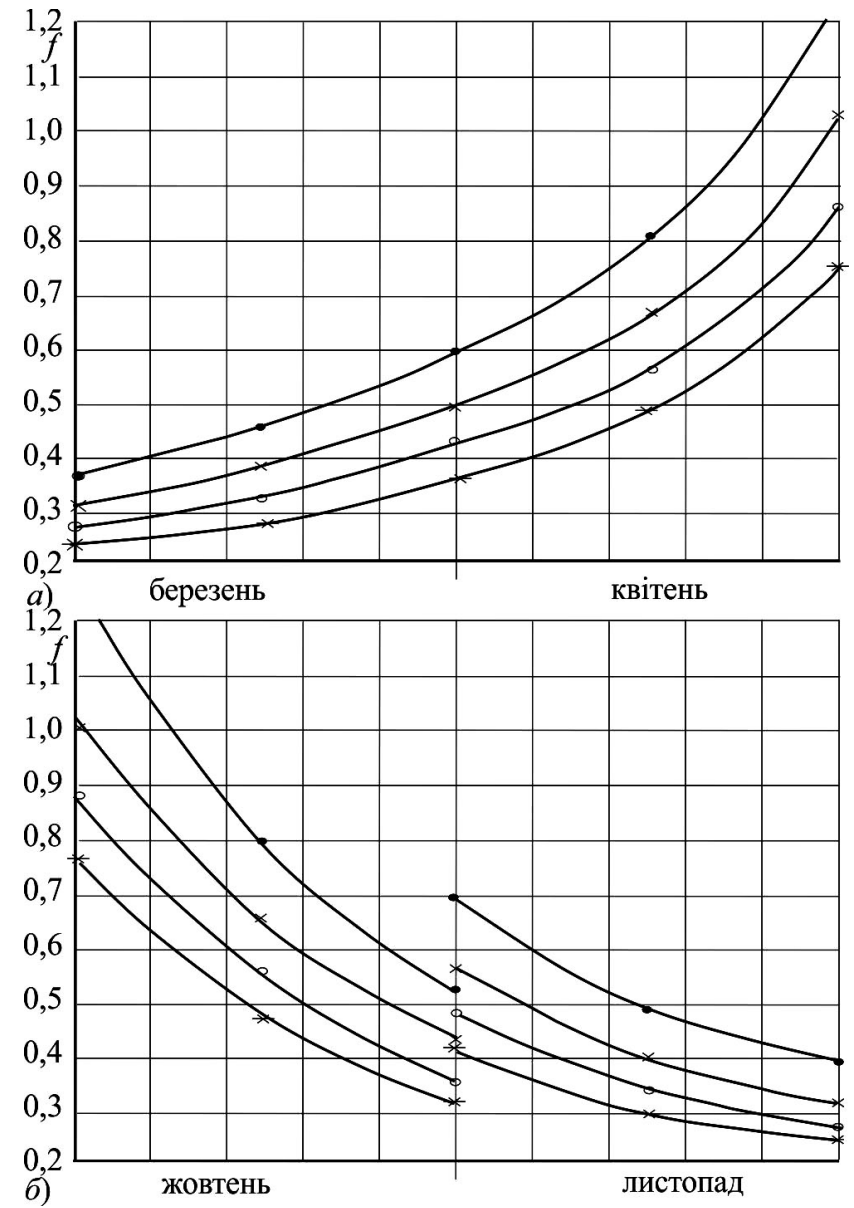

Рис. 3. Залежність коефіцієнта заміщення f для різних значень теплового навантаження $\gamma$
Визначено коефіцієнт заміщення $f$, як частку сонячної енергії в загальній необхідній витраті тепла на опалення приміщення (Tarnizhevskiy, 2000), за формулою

$$
f=\frac{Q_{\text {nрих }}}{Q_{\text {необх }}} .
$$

Отримано графіки часової залежності коефіцієнта заміщення $f$ для різних значень теплового навантаження $\gamma$ в осінні та весняні місяці (див. рис. 3).

Висновки. Отже, на підставі визначених коефіцієнтів заміщення з'ясовано, що ступінь підтримки теплопостачання розглянутої будівлі в Чернівцях за наведених вище їі об'єму, розміру стіни ТМ і теплового щебеневого акумулятора може становити для осінніх і весняних місяців від 25 до 100 \% залежно від значень теплового навантаження $\gamma$.

У плані узагальнення відзначаємо, що подане вище $\epsilon$ наближено справедливим для аналогічних будівель, розташованих у першій кліматичній зоні України, для розрахунків систем сонячного постачання згідно 3 ДСТУ-Н Б В.2.5-43:2010.

\section{Перелік використаних джерел}

Basok, B. I. (2014). Eksperymentalnyi budynok pasyvnoho typu. Enerhoefektyvnist u budivnytstvi ta arkhitekturi, 6, 3-8. [In Ukrainian].

Bellos, E., Tzivanidis, C., Zisopoulou, E., \& Mitsopoulos, G. (2016). An innovative Tromble wall as a passive heating system for a building in Athens. A comparison witsh the Bellos conventional Trombe wall and the insulated wall. Energy and Buildings, 133, 754 769. https://doi.org/10.1016/j.enbuild.2016.10.035

Boyer, H., Miranville, F., Bigot, D., Guichard, S., Idriss, I., \& Jean, F. (2011). Heat transfer in buildings: application to air solar heaiting and Trombe wall. Evaporation, condentasation and heat transfer, 227-244. Retrieved from: https:/hal.archives-ouvertes.fr/hal00767482 .

Bozhko, I. K., Lisenko, O. N., Goncharuk, S. M., \& Kalinina, M. F. (2012). Passivnye doma v Ukraine i v stranakh SNG. Promyshlennaia teplotekhnika, 37(1), 69-81. [In Russian].

DSTU-N B V.2.5-43:2010. (2010). Inzhenerne obladnannia budynkiv i sporud. Nastanova $z$ ulashtuvannia system soniachnoho teplopostachannia $\mathrm{v}$ budynkakh zhytlovoho i hromadskoho pryznachennia. Kyiv: Minrehionbud Ukrainy, 45 p. [In Ukrainian].

Handbook. (2019). Solar Electricity Handbook 2019 Edition. Solar Irradiance. Retrieved from: http://solarelectricityhandbook.com/solarirradiance.html

Honcharuk, S. M., Kalinina, M. F., Bozhko, I. K., Kuzhel, L. M., \& Lysenko, O. M. (2016). Stvorennia eksperymentalnoho enerhoefektyvnoho budynku typu "nul enerhii. Prom. Teplotekhnika, 36(3), 88-95. [In Ukrainian].

Irradiance. (2019). Solar Irradiance figures 2019 Edition. Retrieved from: http://solarelectricityhandbook.com/solar-irradiance.html

Stepanenko, O. I., \& Dubrovska, V. V. (2014). Pasyvnyi budynok shliakh do efektyvnoho vykorystannia enerhii. Enerhetyka, ekonomika, tekhnolohii, ekolohiia, 3, 56-58. [In Ukrainian].

Tarnizhevskii, B. V. (2000). Effektivnost passivnykh sistem solnechnogo otopleniia v klimaticheskikh usloviia Rossii. Teploenergetika, 1, 14-17. [In Russian].

Ukrainskaia SSR. (1990). Nauchno-prikladnoi spravochnik po klimatu SSSR. (Issue 10. Book 1). Lviv: Gidrometeoizdat, 595 p. [In Russian].

Zhijie Yin. (2012). Simulation and Modification of a Composite Trombe Wall to Adapt to the Climate in Victoria. Canada: Northwestern Polytechnical University, 65 p. 
THE PASSIVE SYSTEM OF THE SOLAR HEAT SUPPLY

The aim of our study is to calculate the passive solar heat supply of a building with the Trombe-Michel (TM) wall, which is located in Chernivtsi. The investigated building has the following parameters: heating area $-50 \mathrm{~m}^{2}$, heating volume $-150 \mathrm{~m}^{3}$. In the section, the TM wall has a trapezoidal profile with an inclination of the south side, with an area of $8 \times 2.7 \mathrm{~m}^{2}$, to the plane of the horizon $67^{\circ}$ and orientation to the south. From the south, the TM wall is separated from the outside air by double glazing. The arrival of radiation on the southern surface of the TM wall was determined for the following periods: October-November and March-April. In this case, the absorption coefficient of solar radiation by the surface of the TM wall is assumed to be 0.9 . The loss of radiation when passing through the glazing is assumed to be 0.83 . The average daily heat losses due to the radiation of the surface of the wall into an infinite space with an ambient temperature are determined. At night, the inner side of the glazing is covered with a shield made from a heat-insulating material to reduce heat loss. Being placed in the basement, a gravel battery accumulates about 2 GJ of heat at a temperature of $75^{\circ} \mathrm{C}$ during the summer. The battery is charged by supplying hot air through it, which is heated by solar radiation in the gap between the TM wall and the glazing. In October-November period the air taken by the fan from the room passes through the battery and heated enters the room. This ensures a uniform supply of heat to the premises at a rate of 20 MJ per day for October and $48 \mathrm{MJ}$ per day for November. Heat consumption for heating is determined by dissipative losses due to fencing building constructions and heat consumption during ventilation. The seasonal dependence of the total daily heat input taking into account radiation losses and the use of accumulated heat has been established. The replacement coefficient for heat supply $f$, as part of solar energy in the total required heat consumption for heating, was determined for different values of heat load $\gamma$ (from 0.7 to $1.3 \mathrm{~W} /\left(\mathrm{m}^{3}\right.$ hail)) during the autumn and spring months. It has been established that when using the $T M$ wall, replacement rate $f$ of the heat supply of the building considered in Chernivtsi at the volum indicated above, the size of the TM wall and the heat capacity of the battery can be from 25 to $100 \%$ for the autumn and spring months depending on the values of heat load $\gamma$.

Keywords: Trombe-Michel wall; accumulation of solar energy; thermal load; replacement rate. 